\title{
Analisis Kestabilan Titik Tetap Model Matematika Penyebaran Penyakit DBD Tipe SEIR
}

Elinora Naikteas Bano ${ }^{\mathrm{a}}$

${ }^{a}$ Fakultas Sains dan Teknologi, Universitas Timor, Kefamenanu, TTU - NTT, Indonesia.

\section{Article Info}

Article history:

Received 10 Mei 2018

Received in revised form 14 Juni 2018 Accepted 14 Juli 2018

DOI

https://doi.org/10.32938/slk.v1i1.421

Keywords:

Model Matematika

Titik Tetap

Analisis kestabilan

Titik Tetap

\section{Pendahuluan}

Dengue masih menjadi masalah yang dibicarakan saat ini. Dengue ditularkan ke manusia oleh gigitan nyamuk Aedes aegypti atau Aedes albopictus Infeksi virus dengue berupa demam dengue, Demam Berdarah Dengue (DBD) dan Dengue Shock Syndrome (DSS) yang mempunyai empat jenis serotipe virus yaitu: DEN_1, DEN_2, DEN_3, DEN_4 (Tirtha Chakraborty, 2008).

Manusia yang telah terinfeksi oleh salah satu dari empat jenis serotipe akan tetap potensial menularkan virus dengue kepada manusia rentan lainnya (Ginanjar, 2008). Perlindungan terhadap jenis serotipe terinfeksi akan bertahan lama dan berlangsung rata-rata 2 tahun (WHO, 2016). Model penyebaran penyakit demam berdarah dengue yang dikenalkan oleh peneliti sebelumnya (Derouich $d k k ., 2003$ ) tanpa memperhatikan tahap terpapar (exposed) pada manusia dan nyamuk. Pada pembahasan ini, tahap terpapar (exposed) pada manusia dan nyamuk diperhatikan untuk mempelajari dinamika penyebaran penyakit demam berdarah dengue.

Pembahasan ini dari model hanya dibahas sepintas mengenai analisis kestabilan titik tetap dinamika penyebaran demam berdarah dengue, fokusnya dalam menganalisis kestabilan titik tetap tanpa penyakit dan titik tetap endemik secara analitik. Hasil dari analisis ini dapat digunakan sebagai referensi dalam menangani masalah penyebaran penyakit demam berdarah dengue (DBD).

\section{Model Penyebaran Penyakit Demam Berdarah Dengue}

Model pembahasan pada tulisan ini adalah model dengan asumsiasumsinya telah diperkenalkan oleh (Naikteas Bano $d k k ., 2017)$

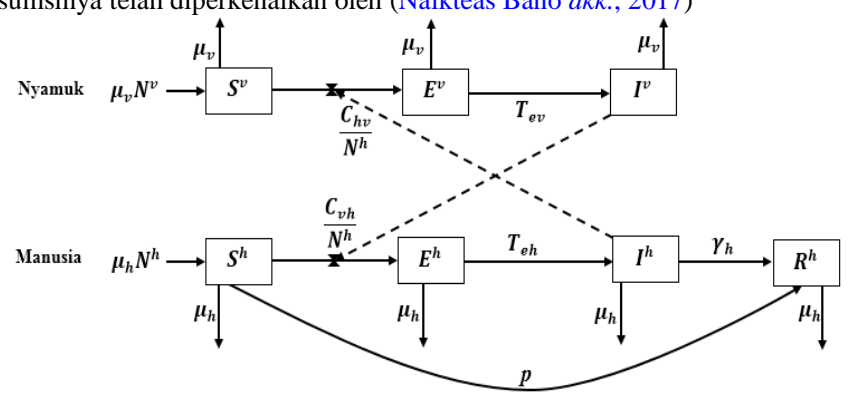

Gambar 1 Diagram kompartemen penyakit

Dari diagram kompartemen tersebut, diperoleh sistem persamaan diferensial berikut:

$$
\left\{\begin{array}{l}
\frac{d S^{h}}{d t}=\mu_{h} N^{h}-\left(\mu_{h}+p+\frac{C_{v h} I^{v}}{N^{h}}\right) S^{h}, \\
\frac{d E^{h}}{d t}=\left(\frac{C_{v h} I^{v}}{N^{h}}\right) S^{h}-\left(T_{e h}+\mu_{h}\right) E^{h}, \\
\frac{d I^{h}}{d t}=T_{e h} E^{h}-\left(\gamma_{h}+\mu_{h}\right) I^{h}, \\
\frac{d R^{h}}{d t}=p S^{h}+\gamma_{h} I^{h}-\mu_{h} R^{h}, \\
\frac{d S^{v}}{d t}=\mu_{v} N^{v}-\left(\mu_{v}+\frac{C_{h v I^{h}}}{N^{h}}\right) S^{v}, \\
\frac{d E^{v}}{d t}=\frac{C_{h v} I^{h}}{N^{h}} S^{v}-\left(T_{e v}+\mu_{v}\right) E^{v}, \\
\frac{d I^{v}}{d t}=T_{e v} E^{v}-\mu_{v} I^{v} .
\end{array}\right.
$$

Kemudian dengan melakukan penyederhanaan dan penskalaan, diperoleh sistem persamaan diferensial berikut:

$$
\left\{\begin{array}{l}
\frac{d S_{h}}{d t}=\mu_{h}-\left(\mu_{h}+p+n C_{v h} I_{v}\right) S_{h}, \\
\frac{d E_{h}}{d t}=\left(n C_{v h} I_{v}\right) S_{h}-\left(T_{e h}+\mu_{h}\right) E_{h}, \\
\frac{d I_{h}}{d t}=T_{e h} E_{h}-\left(\gamma_{h}+\mu_{h}\right) I_{h}, \\
\frac{d E_{v}}{d t}=C_{h v} I_{h}\left(1-E_{v}-I_{v}\right)-\left(T_{e v}+\mu_{v}\right) E_{v}, \\
\frac{d I_{v}}{d t}=T_{e v} E_{v}-\mu_{v} I_{v},
\end{array}\right.
$$

dengan $n=\frac{N^{v}}{N^{h}}$ dan $S_{h}=\frac{S^{h}}{N^{h}}, E_{h}=\frac{E^{h}}{N^{h}}, I_{h}=\frac{I^{h}}{N^{h}}, R_{h}=\frac{R^{h}}{N^{h}}, S_{v}=\frac{S^{v}}{N^{v}}, E_{v}=\frac{E^{v}}{N^{v}}, I_{v}=$ $\frac{I^{v}}{N^{v}}$.

Semua parameter pada persamaan (2) adalah positif dan keterangan parameter disajikan pada Tabel 1 .

Tabel 1. Parameter dalam Model yang Ditunjukkan pada Gambar 1.

\begin{tabular}{cl}
\hline Simbol & \multicolumn{1}{c}{ Keterangan } \\
\hline$p$ & Efektivitas penggunaan vaksin \\
$P_{h v}$ & Efektivitas penularan dari manusia terinfeksi ke nyamuk rentan \\
$P_{v h}$ & Efektivitas penularan dari nyamuk terinfeksi ke manusia rentan \\
$b_{s}$ & Rata-rata gigitan nyamuk rentan \\
$b_{i}$ & Rata-rata gigitan nyamuk terinfeksi \\
$\mu_{h}$ & Laju kelahiran manusia dianggap sama dengan laju kematian \\
$\mu_{v}$ & Laju kelahiran nyamuk dianggap sama dengan laju kematian \\
$C_{h v}$ & Peluang nyamuk rentan dapat terinfeksi \\
$C_{v h}$ & Peluang manusia rentan dapat terinfeksi \\
$\gamma_{h}$ & Proporsi manusia terinfeksi yang sembuh karena pengaruh \\
& kekebalan alami dalam tubuhnya \\
$T_{e h}$ & $\quad$ Waktu inkubasi intrinsik \\
$T_{e v}$ & Waktu inkubasi ekstrinsik \\
$T_{i d}$ & Durasi manusia terinfeksi \\
\hline
\end{tabular}

Kestabilan Sistem

Titik Tetap

Titik tetap diperoleh dengan syarat: $\frac{d S_{h}}{d t}=0, \frac{d E_{h}}{d t}=0, \frac{d I_{h}}{d t}=0, \frac{d E_{v}}{d t}=0$ dan $\frac{d I_{v}}{d t}=0$, sehingga menghasilkan

$\Omega=\left\{\left(S_{h}, E_{h}, I_{h}, E_{v}, I_{v}\right) \in \mathbb{R}_{+}^{5}: E_{v}+I_{v} \leq 1\right.$ dan $\left.\left(1+p / \mu_{h}\right) S_{h}+E_{h}+I_{h} \leq 1\right\}$, dan memiliki dua titik tetap, yaitu titik tetap tanpa penyakit $\left(T_{1}\right)$ dan titik tetap endemik $\left(T_{2}\right)$ yang masing-masing berbentuk:

$T_{1}\left(S_{h}, E_{h}, I_{h}, E_{v}, I_{v}\right)=\left(\mu_{h} /\left(\mu_{h}+p\right), 0,0,0,0\right)$, dan $T_{2}\left(S_{h}^{*}, E_{h}^{*}, I_{h}^{*}, E_{v}^{*}, I_{v}^{*}\right)$

$$
\begin{aligned}
& S_{h}^{*}= \begin{array}{l}
\text { dengan } \\
\left.T_{e v}+\mu_{v}\right)\left(C_{h v} T_{e h} \mu_{h}+\left(T_{e h}+\mu_{h}\right) \mu_{v}\right)
\end{array} \\
& C_{h v} T_{e h}\left(C_{v h} n T_{e v}+\left(p+\mu_{h}\right)\left(T_{e v}+\mu_{v}\right)\right)^{*} \frac{C_{h v} C_{v h} n T_{e h} T_{e v} \mu_{h}-\left(p+\mu_{h}\right)\left(T_{e h}+\mu_{h}\right)\left(\gamma_{h}+\mu_{h}\right) \mu_{v}\left(T_{e v}+\mu_{v}\right)}{C_{h v} T_{e h}\left(T_{e h}+\mu_{h}\right)\left(C_{v h} n T_{e v}+\left(p+\mu_{h}\right)\left(T_{e v}+\mu_{v}\right)\right)}, \\
& I_{h}^{*}=\frac{C_{h v} C_{v h} n T_{e h} T_{e v} \mu_{h}-\left(p+\mu_{h}\right)\left(T_{e h}+\mu_{h}\right)\left(\gamma_{h}+\mu_{h}\right) \mu_{v}\left(T_{e v}+\mu_{v}\right)}{C_{h v}\left(T_{e h}+\mu_{h}\right)\left(\gamma_{h}+\mu_{h}\right)\left(C_{v h} n T_{e v}+\left(p+\mu_{h}\right)\left(T_{e v}+\mu_{v}\right)\right)}
\end{aligned}
$$


$E_{v}^{*}=\frac{\mu_{v}\left(-C_{h v} C_{v h} n T_{e h} T_{e v} \mu_{h}+\left(p+\mu_{h}\right)\left(T_{e h}+\mu_{h}\right)\left(\gamma_{h}+\mu_{h}\right) \mu_{v}\left(T_{e v}+\mu_{v}\right)\right)}{C_{v h} n T_{e v}\left(T_{e v}+\mu_{v}\right)\left(C_{h v} T_{e h} \mu_{h}+\left(T_{e h}+\mu_{h}\right)\left(\gamma_{h}+\mu_{h}\right) \mu_{v}\right)}$, $I_{v}^{*}=\frac{C_{h v} C_{v h} n T_{e h} T_{e v} \mu_{h}-\left(p+\mu_{h}\right)\left(T_{e h}+\mu_{h}\right)\left(\gamma_{h}+\mu_{h}\right) \mu_{v}\left(T_{e v}+\mu_{v}\right)}{C_{v h} n T_{e v}\left(T_{e v}+\mu_{v}\right)\left(C_{h v} T_{e h} \mu_{h}+\left(T_{e h}+\mu_{h}\right)\left(\gamma_{h}+\mu_{h}\right) \mu_{v}\right)}$.

Sifat kestabilan di sekitar titik tetap $T_{1}$ dan $T_{2}$ dianalisis menggunakan kriteria Routh-Hurwitz (Edelstein-Keshet, 1988) dengan software Mathematicha 10.0 .

\section{Bilangan Reproduksi Dasar $\left(\mathcal{R}_{0}\right)$}

Bilangan reproduksi dasar adalah nilai harapan banyaknya populasi rentan menjadi terinfeksi. Jika $\mathcal{R}_{0}<1$, maka penyakit akan menghilang dari populasi. Jika $\mathcal{R}_{0}>1$, maka penyakit akan meningkat menjadi wabah. Bilangan reproduksi dasar untuk persamaan (2), diperoleh menggunakan metode the next generation matrix (van den Driessche, 2017), yakni:

$$
\mathcal{R}_{0}=\frac{C_{h v} C_{v h} n T_{e h} T_{e v} \mu_{h}}{\left(p+\mu_{h}\right)\left(T_{e h}+\mu_{h}\right)\left(\gamma_{h}+\mu_{h}\right) \mu_{v}\left(T_{e v}+\mu_{v}\right)} .
$$

\section{Metode}

Penelitian ini menggunakan software Mathematica 10.0 untuk membantu dalam mencari solusi analitik. Penelitian ini dilakukan dengan menganalisis kestabilan titik tetap model penyebaran penyakit demam berdarah dengue (DBD).

\section{Hasil dan Pembahasan}

Analisis Kestabilan Titik Tetap Tanpa Penyakit $\left(T_{1}\right)$

Untuk menentukan kestabilan di sekitar titik tetap tanpa penyakit $\left(T_{1}\right)$, terlebih dahulu dilakukan pelinearan (Tu, 2012) terhadap persamaan (2), untuk memperoleh matriks Jacobi berikut:

$$
J_{T_{1}}=\left[\begin{array}{ccccc}
D_{1} & 0 & 0 & 0 & D_{2} \\
0 & D_{3} & 0 & 0 & D_{4} \\
0 & D_{5} & D_{6} & 0 & 0 \\
0 & 0 & D_{7} & D_{8} & 0 \\
0 & 0 & 0 & D_{9} & D_{10}
\end{array}\right],
$$

dengan

$D_{1}=-\left(p+\mu_{h}\right), D_{2}=-\frac{C_{v h} n \mu_{h}}{p+\mu_{h}}, D_{3}=-\left(T_{e h}+\mu_{h}\right), D_{4}=\frac{C_{v h} n \mu_{h}}{p+\mu_{h}}, D_{5}=T_{e h}$

$D_{6}=-\left(\gamma_{h}+\mu_{h}\right), D_{7}=C_{h v}, D_{8}=-\left(T_{e v}+\mu_{v}\right), D_{9}=T_{e v}, D_{10}=-\mu_{v}$.

Selanjutnya nilai eigen diperoleh berdasarkan persamaan karakteristik berikut:

$\left(-p-\lambda-\mu_{h}\right)\left(-\frac{C_{h v} C_{v h} n T_{e h} T_{e v} \mu_{h}}{p+\mu_{h}}+\left(\lambda+T_{e h}+\mu_{h}\right)\left(\lambda+\gamma_{h}+\mu_{h}\right)\left(\lambda+\mu_{v}\right)(\lambda+\right.$

$\left.\left.T_{e v}+\mu_{v}\right)\right)=0$.

Berdasarkan persamaan di atas diperoleh:

$$
\lambda=-\left(p+\mu_{h}\right)
$$

dan persamaan karakteristik:

$$
\lambda^{4}+a_{1} \lambda^{3}+a_{2} \lambda^{2}+a_{3} \lambda+a_{4}=0
$$

dengan

$a_{1}=\left(\gamma_{h}+\mu_{h}\right)+\left(T_{e h}+\mu_{h}\right)+\mu_{v}+\left(T_{e v}+\mu_{v}\right)>0$,

$a_{2}=\left(T_{e h}+\mu_{h}\right)\left(\gamma_{h}+\mu_{h}\right)+\mu_{v}\left(\left(\gamma_{h}+\mu_{h}\right)\left(T_{e h}+\mu_{h}\right)\right)+\left(T_{e v}+\mu_{v}\right)\left(\left(\gamma_{h}+\right.\right.$

$\left.\left.\mu_{h}\right)+\left(T_{e h}+\mu_{h}\right)+\mu_{v}\right)>0$,

$a_{3}=\mu_{v}\left(\gamma_{h}+\mu_{h}\right)\left(T_{e h}+\mu_{h}\right)+\left(T_{e v}+\mu_{v}\right)\left(T_{e h}+\mu_{h}\right)\left(\gamma_{h}+\mu_{h}\right)+\mu_{v}\left(T_{e v}+\right.$

$\left.\mu_{v}\right)\left(\gamma_{h}+\mu_{h}\right)\left(T_{e h}+\mu_{h}\right)>0$,

$a_{4}=\mu_{v}\left(T_{e v}+\mu_{v}\right)\left(\gamma_{h}+\mu_{h}\right)\left(T_{e h}+\mu_{h}\right)\left(1-\mathcal{R}_{0}\right) \cdot\left(\mathcal{R}_{0}\right.$ ada pada persamaan 3$)$

Berdasarkan kriteria Routh-Hurwitz, persamaan karakteristik (4) pada titik tetap $T_{1}$ stabil jika memenuhi syarat-syarat kestabilan berikut:

$a_{1}>0$ dan $a_{2}>0$ dan $a_{3}>0$ dan $a_{4}>0$ dan $a_{1} a_{2} a_{3}>\left(a_{3}^{2}+a_{1}^{2} a_{4}\right)$,

karena semua parameter bernilai positif, maka nilai $a_{1}, a_{2}$ dan $a_{3}$ bernilai positif. Koefisien $a_{4}$ akan bernilai positif, negatif atau nol bergantung pada nilai $\mathcal{R}_{0}$. Jika $\mathcal{R}_{0}<1$, maka $a_{4}>0$. Jika $\mathcal{R}_{0}=1$, maka $a_{4}=0$. Jika $\mathcal{R}_{0}>1$, maka $a_{4}<0$.
Berdasarkan kondisi $\mathcal{R}_{0}<1$ yaitu $a_{4}>0$, diperoleh $a_{1} a_{2} a_{3}>\left(a_{3}^{2}+\right.$ $a_{1}^{2} a_{4}$ ). Sehingga untuk $\mathcal{R}_{0}<1$, kondisi (5) terpenuhi. Sedangkan untuk kondisi $\mathcal{R}_{0}>1$ yaitu $a_{4}<0$ dan $\mathcal{R}_{0}=1$ yaitu $a_{4}=0$, berlawanan dengan kondisi (5) akibatnya kriteria Routh-Hurwitz tidak terpenuhi.

Dengan demikian dapat disimpulkan bahwa karena nilai $\lambda<0$ dan jika $\mathcal{R}_{0}<1$ kriteria Routh-Hurwitz telah ditunjukkan terpenuhi, maka titik tetap tanpa penyakit $\left(T_{1}\right)$ stabil manakala $\mathcal{R}_{0}<1$.

\section{Analisis Kestabilan Titik Tetap Endemik $\left(\boldsymbol{T}_{2}\right)$}

Untuk menentukan kestabilan di sekitar titik tetap endemik $\left(T_{2}\right)$, terlebih dahulu dilakukan pelinearan $(\mathrm{Tu}, 2012)$ terhadap persamaan $(2)$, untuk memperoleh matriks Jacobi berikut:

$$
J_{T_{2}}=\left[\begin{array}{ccccc}
D_{1} & 0 & 0 & 0 & D_{2} \\
D_{3} & D_{4} & 0 & 0 & D_{5} \\
0 & D_{6} & D_{7} & 0 & 0 \\
0 & 0 & D_{8} & D_{9} & D_{10} \\
0 & 0 & 0 & D_{11} & D_{12}
\end{array}\right],
$$

dengan nilai $D_{1}, D_{2}, D_{3}, D_{4}, D_{5}, D_{6}, D_{7}, D_{8}, D_{9}, D_{10}, D_{11}$, dan $D_{12}$ dapat dilihat pada Lampiran 1.

Kemudian nilai eigen diperoleh dari persamaan karakteristik berikut:

$$
\lambda^{5}+b_{1} \lambda^{4}+b_{2} \lambda^{3}+b_{3} \lambda^{2}+b_{4} \lambda+b_{5}=0,
$$

dengan nilai $b_{1}, b_{2}, b_{3}, b_{4}$ dan $b_{5}$ dapat dilihat pada Lampiran 2 .

Berdasarkan kriteria Routh-Hurwitz, persamaan karakteristik (6) pada titik tetap $T_{2}$ stabil jika dan hanya jika memenuhi syarat-syarat kestabilan berikut: $b_{1}>0$ dan $b_{2}>0$ dan $b_{3}>0$ dan $b_{4}>0$ dan $b_{5}>0$ dan $b_{1} b_{2} b_{3}>\left(b_{3}^{2}+b_{1}^{2} b_{4}\right) \quad$ dan $\quad\left(b_{1} b_{4}-b_{5}\right)\left(b_{1} b_{2} b_{3}-b_{3}^{2}+b_{1}^{2} b_{4}\right)>b_{5}\left(b_{1} b_{2}-\right.$ $\left.b_{3}\right)^{2}+b_{1} b_{5}^{2}$. (7)

Karena semua parameter bernilai positif, maka nilai $b_{1}, b_{2}$ dan $b_{3}$ bernilai positif. Koefisien $b_{4}$ bernilai positif saat kondisi $\mathcal{R}_{0}<1, \mathcal{R}_{0}=1$ dan $\mathcal{R}_{0}>1$. Anggap jika $\mathcal{R}_{0}>1$, maka $b_{4}>0$. Koefisien $b_{5}$ bernilai positif, negatif atau nol bergantung pada nilai $\mathcal{R}_{0}$. Jika $\mathcal{R}_{0}<1$, maka $b_{5}<0$. Jika $\mathcal{R}_{0}=1$, maka $b_{5}=0$. Jika $\mathcal{R}_{0}>1$, maka $b_{5}>0$. Berdasarkan kondisi $\mathcal{R}_{0}>1$ yaitu $b_{4}>0$ dan $b_{5}>$ 0 diperoleh $b_{1} b_{2} b_{3}>\left(b_{3}^{2}+b_{1}^{2} b_{4}\right)$ dan $\left(b_{1} b_{4}-b_{5}\right)\left(b_{1} b_{2} b_{3}-b_{3}^{2}+b_{1}^{2} b_{4}\right)>$ $b_{5}\left(b_{1} b_{2}-b_{3}\right)^{2}+b_{1} b_{5}^{2}$ sehingga untuk $\mathcal{R}_{0}>1$, kondisi (7) terpenuhi. Sedangkan untuk kondisi $\mathcal{R}_{0}<1$ yaitu $b_{5}<0$ dan $\mathcal{R}_{0}=1$ yaitu $b_{5}=0$ berlawanan dengan kondisi (7) akibatnya kriteria Routh-Hurwitz tidak terpenuhi. Dengan demikian dapat disimpulkan bahwa jika $\mathcal{R}_{0}>1$ kriteria Routh-Hurwitz terpenuhi, maka titik tetap $T_{2}$ akan stabil manakala $\mathcal{R}_{0}>1$.

\section{Simpulan}

Berdasarkan analisis dan pembahasan yang dilakukan terhadap diagram kompartemen modifikasi dapat disimpulkan bahwa terdapat dua titik tetap yaitu titik tetap tanpa penyakit dan titik tetap endemik. Model matematika ini memiliki bilangan reproduksi dasar (basic reproduction number) $\left(\mathcal{R}_{0}\right)$, dimana dengan menggunakan kriteria Routh-Hurwitz dapat dibuktikan bahwa titik tetap tanpa penyakit stabil untuk kondisi ketika $\mathcal{R}_{0}<1$. Sedangkan titik tetap endemik stabil untuk kondisi ketika $\mathcal{R}_{0}>1$.

\section{Pustaka}

Derouich, M., Boutayeb, A. \& Twizell, E. 2003. A model of dengue fever. BioMedical Engineering OnLine, 2(1): 4.

Van Den Driessche, P. 2017. Reproduction Numbers Of Infectious Disease Models. Infectious Disease Modelling, 2(3): 288-303.

Edelstein-Keshet, L. 1988. Mathematical models in biology. Siam.

Ginanjar, G. 2008. Demam Berdarah. PT Mizan Publika.

Naikteas Bano, E., Sianturi, P. \& Jaharuddin 2017. Model Matematika Penyebaran Penyakit Demam Berdarah Dengue Tipe SEIR Iinfeksi Ganda. Repository Institut Pertanian Bogor. Tersedia di https://repository.ipb.ac.id.

Tirtha Chakraborty 2008. Dengue Fever and Other Hemorrhagic Viruses. New York: Chelsea House.

Tu, P.N. 2012. Dynamical systems: an introduction with applications in economics and biology. Springer Science \& Business Media.

WHO 2016. Dengue: Immunization, Vaccines and Biologicals. Media Center WHO [Internet]. http://www.who.int/immunization/diseases/dengue 